\title{
Recovery rates of bluetongue virus serotypes 1, 2, 4 and 8 Spanish strains from orally infected Culicoides imicola in South Africa
}

\author{
R. DEL RÍO LÓPEZ ${ }^{1}$, M.A. MIRANDA ${ }^{1}$, C. PAREDES-ESQUIVEL ${ }^{1}$, J. LUCIENTES ${ }^{2}$, C. \\ CALVETE $^{3}$, R. ESTRADA ${ }^{2}$ and G.J. VENTER ${ }^{4,5}$ \\ ${ }^{1}$ Laboratory of Zoology and Emerging Diseases, UIB-IUNICS, Cra. Valldemossa km 7.5, Palma de \\ Mallorca, Illes Balears, Spain CP: 07122, ${ }^{2}$ Departamento de Patología Animal, Facultad de Veterinaria \\ de Zaragoza, Zaragoza, Spain, ${ }^{3}$ Unidad de Sanidad y Producción Animal, Centro de Investigación y \\ Tecnología Agroalimentaria (CITA), Gobierno de Aragón, Zaragoza, Spain. ${ }^{4}$ Parasites, Vectors and \\ Vector Borne Diseases, Agricultural Research Council - Onderstepoort Veterinary Institute, \\ Onderstepoort 0110, South Africa, ${ }^{5}$ Department of Veterinary Tropical Diseases, University of Pretoria, \\ Onderstepoort 0110, South Africa.
}

\begin{abstract}
Bluetongue (BT) is an infectious disease of ruminants that has spread northwards in Europe during the last decade. The aetiological agent of the disease is an arbovirus (Bluetongue) which belongs to the genus Orbivirus (family Reoviridae) and it is transmitted by certain species of biting midges within the genus Culicoides (Diptera: Ceratopogonidae). Information regarding the vector status of the Culicoides species in a specific area will be essential to predict the risk of a BTV incursion. Field collected Culicoides (Avaritia) imicola Kieffer from South Africa were fed on blood containing several Spanish isolates of BTV. Despite the high virus concentrations in the blood meal (5.1-6.4 $\log _{10} \mathrm{TCID}_{50} / \mathrm{ml}$ of blood), virus was recovered from $<1 \%$ of midges assayed after incubation. Virus concentrations $>2.5 \log _{10} \mathrm{TCID}_{50} /$ midge in individual infected $C$. imicola suggest virus replication with possible risk of transmission to susceptible vertebrate hosts in the field for at least two of the serotypes assayed (BTV1 and BTV2). A third serotype (BTV4) was very close to the stimated threshold of transmission. The relatively low to near refractory status of $C$. imicola compared to other vector species like $C$. bolitinos supports previous results, indicating that Culicoides species other than C. imicola may play a more important role in the epidemiology of BTV.
\end{abstract}

Keywords: Culicoides imicola, bluetongue virus, infection rate, oral susceptibility, vector

capability

Correspondence: Ricardo del Río, Laboratory of Zoology and Emerging Diseases, UIB-IUNICS, Cra.

Valldemossa km 7.5, Palma de Mallorca, Illes Balears, Spain CP: 07122; Tel.: +34 971173352; Fax: +34

971173184; E-mail: ricardo.delrio@uib.es

\section{INTRODUCTION}

Bluetongue (BT) is an infectious viral disease of wild and domestic ruminants that can severely affects domestic sheep and sometimes cattle. The causative agent, bluetongue virus 
(BTV), genus Orbivivirus, family Reoviridae (Borden et al., 1971), is transmitted by several Culicoides species (Diptera: Ceratopogonidae) (Mellor et al., 2000). Before 2000 BTV was believed to be restricted to an area between $40^{\circ} \mathrm{N}$ and $35^{\circ} \mathrm{S}$ (Walton, 2004), however, during the last decade, it has expanded northwards in Europe up to $50^{\circ} \mathrm{N}$ (OIE, 2006; Carpenter et al., 2009). This expansion of the infection and associated vectors has been postulated as partly ascribed to climate change (Purse et al., 2005).

24 BTV serotypes of the virus are recognised worldwide (OIE, 2009), however, recent studies seem to indicate that two more serotypes could be implicated in the epidemiology of the disease ( Hofmann et al., 2008; Maan 2011). BTV-10 was the first to be recorded in mainland Spain between 1956 and 1960. The outbreaks occurred during those years were attributed to infected Culicoides transported by wind from North Africa resulting in the death of more than 100000 sheep (Manso-Ribeiro \& Norenha, 1958; Campano-Lopez \& Sanchez-Botija, 1958, Sellers et al., 1978). Forty years later, in October 2000, bluetongue disease struck Spain again. The serotype was identified as BTV-2 and caused 305 outbreaks in the Balearic Islands (Miranda et al., 2003). Three years later, BTV-4 was reported in the eastern part of Menorca, and in October 2004 in mainland Spain affecting the province of Cádiz and spreading rapidly north and south (Gómez-Tejedor, 2004). Despite vaccination with live-attenuated BTV-4 vaccine (Gómez-Tejedor, 2004), this serotype continued to spread northwards during the summer of 2005 into provinces in Andalucia, Castilla la Mancha, Castilla y León, Extremadura and Madrid. In addition, BTV-2 was also isolated from sentinel cattle in Spain in 2005 (Mellor et al., 2008). In 2007 another serotype, BTV-1, appeared for the first time in Andalucia (Allepuz et al., 2010) and in 2009 it spread to the northwest causing 240 outbreaks in cattle and sheep (Sabirovic et al., 2009). In January 2008, BTV-8 occurred in northern Spain and spread to the southern part of the Iberian Peninsula in October 2008 (Lorca et al., 2011).

Based on its confirmed vector status and host preference for large livestock, the AfroAsiatic Culicoides (Avaritia) imicola Kieffer is considered to be the principal vector of BTV in South Africa (Nevill et al., 1992ab; Meiswinkel et al., 2004) and also across vast geographic regions of Africa and southern Europe (Mellor et al., 1985; Boorman, 1986; Mellor, 1992; 
Mellor et al., 2000, 2009). The oral susceptibility of C. imicola to various strains of BTV has been demonstrated on several occasions in the laboratory (Venter et al., 2010). Field isolations of BTV from this species also support laboratory results (Meiswinkel et al., 2004; Venter et al., 2006).

Distribution and modelling studies of C. imicola in Spain showed that outbreaks of BTV in 2007 were almost exclusively restricted to areas with high numbers of this species (Acevedo et al., 2010). Nevertheless, about $5 \%$ of those localities, where $C$. imicola was predicted to be absent, had experienced at least one outbreak of BTV in the past (Acevedo et al., 2010). In addition, recent studies conducted in Europe associate transmission of several serotypes of the virus with Culicoides species belonging to the Pulicaris and Obsoletus groups (Mellor \& Pitzolis 1979; Savini et al., 2005; Ferrari et al, 2005).

In order to elucidate the role of the proven vector C. imicola in the epidemiology of BTV, the oral susceptibility of this species for those BTV serotypes circulating in Spain was determined.

\section{Material and methods}

Viruses and insects

In the absence of either large populations or laboratory colonies of C. imicola in Spain which are necessary for conducting this type of trial, adults of this species were collected in South Africa using the Onderstepoort black light trap as described by Venter et al. (1998). Traps were placed close to cattle stabled at the Agricultural Research Council-Onderstepoort Veterinary Institute $\left(25^{\circ} 29^{\prime} \mathrm{S}, 28^{\circ} 11^{\prime} \mathrm{E} ; 1219\right.$ m a.s.1.) in South Africa.

Field collected Culicoides midges were fed on blood-BTV mixtures between April and May 2009 in nine separate feeding attempts.

The four BTV serotypes responsible for recent outbreaks in Spain (BTV-1, -2, -4 and -8 ) were obtained from the National Reference Laboratory in Algete, Madrid (Spain). Stocks of virus for infection studies were grown in baby hamster kidney cells (BHK-21). Viruses were titrated and stored as described by Venter et al., 1998. The details of each are shown in Table 1. 


\section{Feeding technique}

After acclimatization in the insectary for $2-3$ days at $23.5^{\circ} \mathrm{C}$ and $50-70 \% \mathrm{RH}$, fieldcollected midges were held without nutrients nor water for 24 hours before blood feeding. $5 \mathrm{ml}$ of stock virus was mixed, immediately before feeding, with $5 \mathrm{ml}$ of blood obtained from a BTV antibody negative sheep. Sheep used for oral susceptibility studies were kept under insect free conditions and were monitored daily for disease symptoms in order to prevent any field virus infections of the animals. Flies were fed through one-day-old chicken skin membrane in batches of 250-300 for 30-45 minutes on defibrinated blood containing one of the four serotypes (Venter et al., 1998). During feeding, lighting in the room was dimmed to $\approx 1 \%$ daylight ( $\approx 65$ lux) while the blood-virus mixture was maintained at $35.5^{\circ} \mathrm{C}$ and stirred continuously to prevent settling of blood cells (Venter et al., 1998).

After feeding, midges were immobilized at $-20^{\circ} \mathrm{C}$ for about a minute. Blood-engorged females were separated out on a chill-table and kept in $250 \mathrm{ml}$ unwaxed paper cups, closed with fine mesh, at $23.5^{\circ} \mathrm{C}$ and $50-70 \%$ relative humidity at $\approx 1 \%$ daylight for the 10 -day extrinsic incubation period. Culicoides females were maintained on $5 \%(\mathrm{w} / \mathrm{v})$ sucrose solution and, in order to improve the survival rate, $500 \mathrm{IU}$ penicillin, $500 \mu \mathrm{g}$ streptomycin and $1.25 \mu \mathrm{g}$ fungizone per ml of solution was added. Females surviving the incubation period were sorted into species on a chill-table and stored individually in $1.5 \mathrm{ml}$ microfuge tubes at $-70^{\circ} \mathrm{C}$ until assayed.

\section{Processing of Culicoides and virological assays}

Midges were assayed for virus immediately after feeding (10 blood engorged midges per feeding attempt) and also after 10 days extrinsic incubation. Processing of individual midges for microtitration assays was carried out as described by Paweska et al. (2002).

The identity of all virus isolates was determined by a microtitre virus-neutralisation procedure (House et al., 1990), using type-specific antisera produced in guinea pigs. Virus concentrations were calculated by the method of Kärber (1931). Statistical differences between experimental groups were analyzed using Chi-square analysis. $P$-values of $<0.05$ were used as the cut-off for statistical significance. 


\section{RESULTS}

Culicoides feeding and survival rates

Feeding rates varied from 10 to $70 \%$ and the virus concentrations in blood meals ranged from 5.1 (BTV-2) to 6.4 (BTV-1) $\log _{10} \mathrm{TCID}_{50} / \mathrm{ml}$ (Table 2). 3573 out of 6063 field collected midges (58.4\%), fed on the four serotypes of BTV, survived the 10-day extrinsic incubation period.

Virus recovery in midges

Due to bacterial and fungal contamination, results could not be obtained neither from midges tested immediately after feeding nor from all the surviving midges assayed after incubation. The number of midges from which results could be obtained is shown in Table 2 .

Only three (BTV-1, -2, -4), of the four serotypes used, were recovered from C. imicola after 10 days at $23.5^{\circ} \mathrm{C}$. The highest virus recovery rate $(0.5 \%)$ was obtained for BTV-2, while recovery rates for BTV-1 and BTV-4 was $0.2 \%$. No significant difference $\left(\chi^{2}=2.543\right.$, d.f $=3$, $P=0.467)$ in the infection prevalence for the four different serotypes was obtained. All isolates from infected midges were serotyped as the same used to spike the blood.

Virus titres in the infected midges ranged from 1.4 to $3.9 \log _{10} \mathrm{TCID}_{50} /$ midge (mean 2.2 $\log _{10} \mathrm{TCID}_{50} /$ midge). Titres of at least $2.5 \log _{10} \mathrm{TCID}_{50} /$ midge were demonstrated for BTV-1 and BTV-2 (Table 2).

Few specimens of Culicoides (Avaritia) bolitinos Meiswinkel, Culicoides (Remia) enderleini Cornet and Brunhes, and Culicoides (Remia) nevilli Cornet and Brunhes, survived the 10-day incubation period. No virus was isolated from any of those specimens (Table 2).

\section{DISCUSSION}

In the present study, field collected Culicoides midges were not screened for the presence of field viruses, but virus recovery from field collected vector populations is generally very low (Chiang \& Reeves, 1962; Walter et al., 1980; Gerry et al., 2001; Venter et al., 2006a). In a field survey conducted in South Africa (endemic for BT) from 1979 to 1985, the virus was isolated from only 526 out of 4506 Culicoides pools (pool size 100-100 000 individuals) (Nevill et al., 
1992a). Using an average of 1000 midges per pool, the field infection prevalence would be $0.06 \%$. The whole South Africa is endemic for BT and during the time of the study no cases of BT were reported. For these reasons it is therefore likely that the infection rate obtained reflects the laboratory conditions and that any influence by field infections should be minimal. This is supported by the fact that the identities of all serotypes recovered from the midges were the same as those used to spike the blood meal.

The infection prevalence obtained (i.e. percentage of midges from which virus could be recovered after the incubation period) was very low compared to other susceptibility studies with different strains of the virus, and ranged from $0.0 \%(\mathrm{BTV}-8)$ to $0.5 \%(\mathrm{BTV}-2)$. The highest recovery rate $(0.5 \%)$ was obtained for BTV-2 being also the serotype with the lowest virus titre in the blood meal. Despite the relatively high virus concentration of BTV-8 in the blood meal $\left(6.1 \log _{10} \mathrm{TCID}_{50} / \mathrm{ml}\right)$, this serotype was not recovered from the midges after the extrinsic incubation period (Table 2). The fact that BTV-8 was not recovered from C. imicola does not necessarily mean that this species is refractive to infection with that serotype. Based on the number of midges assayed it can be concluded that the infection prevalence for this strain was $<0.2 \%$. Statistically, the virus recovery rate of BTV-8 was not significantly different from that of the other three serotypes.

Low virus recovery rates, as an indication of vector competence, does not necessary translate to a low vector capacity for $C$. imicola with the serotypes/strains used. Based on light trap results, $C$. imicola is a widespread species in South Africa and found in very high numbers near livestock (Meiswinkel et al., 2004). This super abundance and host preference of $C$. imicola can compensate for the low infection rates observed. Indeed, this species is considered to have the highest vector capacity for orbiviruses in South Africa (Nevill et al., 1992b; Meiswinkel et al., 2004). Although C. imicola in the Mediterranean basin is not as abundant as in Africa, its role as a competent vector for BTV in this area is enhanced by the presence of relatively high numbers of naïve or unvaccinated hosts due to non persistent vaccinations campaigns. Sheep in these regions, therefore, do not develop effective immunocompetent responses to the infection. The higher susceptibility of European breeds of sheep (Erasmus \& 
Potgieter, 2009), compared to South African sheep breeds, may also play a role in the epidemiology of this disease in Europe.

The minimum level of viraemia in a host, necessary to infect Culicoides vectors, is not known. Based on the blood-meal size for C. imicola (0.01-0.06 $\mu$ l) (Venter et al., 2005) theoretically a minimum of $5.0 \log _{10} \mathrm{TCID}_{50} / \mathrm{ml}$ would be needed to ensure that each individual midge will be exposed to approximately one $\mathrm{TCID}_{50} /$ blood-meal. This value does not take into account the elimination of the excess of liquid taken while feeding. It has been said that virus concentrations as low as $2.0 \log _{10} \mathrm{TCID}_{50} / \mathrm{ml}$ are sufficient to produce infection rates of $0.2 \%$ in Culicoides (Avaritia) brevitarsis Kieffer (Muller et al., 1982), a species similar in size to $C$. imicola. In the USA Bonneau et al (2002) succeeded in infecting Culicoides (Monoculicoides) sonorensis Wirth \& Jones by feeding them on a BTV infected sheep with no detectable viraemia $\left(<0.5 \log _{10} \mathrm{TCID}_{50} / \mathrm{ml}\right.$ of blood $)$. It is therefore clear that the virus titres used in the present study $\left(>5.1 \log _{10} \mathrm{TCID}_{50} / \mathrm{ml}\right.$ of blood) were more than enough to infect all susceptible Culicoides and that the infection prevalence obtained is an indication of the susceptibility rate of this C. imicola population for the viral strains used.

Some studies show that concentrations of live virus $>2.5 \log _{10} \mathrm{TCID}_{50} /$ midge in its head or body is an indicator of a fully disseminated infection (Jennings \& Mellor 1987; Fu et al., 1999; Riegler, 2002). This threshold value $\left(>2.5 \log _{10} \mathrm{TCID}_{50} /\right.$ midge) was derived from $C$. sonorensis studies and may not be applicable for interpretation of vector competence results in other Culicoides species like C. imicola. The virus titres recorded in individual infected C. imicola in the present study indicate that the virus had replicated in the insect to high levels in two of the serotypes assayed (BTV1 and BTV2) and, consequently, onwards transmission to susceptible vertebrate hosts might be possible. A titre of $2.4 \mathrm{TCID}_{50} /$ midge was obtained for BTV4. This value was very close to the stimated threshold of transmission in $C$. sonorensis. Due to the smaller size of C.imicola compared to that of $C$. sonorensis and observing that this serotype circulated in several outbreaks in Spain in areas where $C$. imicola was present (Gómez-Tejedor, 2004), it can be postulated that the Spanish strain of BTV4 could also be transmitted by the South African population of C. imicola. 
Although the current study indicates a very low vector competence of $C$. imicola for the serotypes used, it also shows that this species is susceptible to infection with those isolates and that onwards transmission is possible. In Europe, C. imicola has been recorded in the Iberian Peninsula, the Balearic Islands, Greece, Italy, and the South of France and was thought to be the main vector of BTV in those areas (Miranda et al., 2003; Goffredo et al., 2001; Giovannini et al., 2004; Sarto i Monteys et al., 2005; Purse et al., 2005). Climate change has created milder winter conditions in the northern regions, and recent studies describe an apparent on-going range expansion of this species northwards (Mellor \& Wittmann, 2002; Calvete et al., 2006). In addition to the range expansion, milder conditions can also influence the vector competence of Culicoides species leading to an exponential increase in vector capacity (Mullens et al., 2004).

The relatively low susceptibility results obtained in the present study support the notion that BT might be a "multi-vector" disease and this will add to the complexity of the epidemiology of BTV.

It should also be noted that the susceptibility of a single Culicoides population to infection with different strains of orbiviruses may differ significantly over time (e.g. BTV serotypes: Jones \& Foster, 1978; African horse sickness virus serotype 7 strains: Venter \& Paweska, 2007). Field populations of Culicoides species can vary broadly in their genetic susceptibility to BTV infection. Indeed, it has been demonstrated that some populations of the same species might be completely refractory to infection by some serotypes (Ward, 1994; Mellor, 2004, Carpenter et al., 2006). True assessment of vector competence might be difficult to calculate as it would require some level of real-time monitoring, e.g. testing local Culicoides populations using variants of orbiviruses in current local circulation. Thus, the current study should be repeated with the European populations of $C$. imicola, and extended to other potential vector species such as those included in the Obsoletus group, in order to assay their implication in the epidemiology of BT in places where several species of either proven or suspected and potential vectors are present. The lack of established laboratory colonies of C. imicola in Europe, as well as the lower population abundance of this species compared to that in Africa, may represent a 
serious obstacle to develop such type of oral susceptibility trials in the southern European countries.

\section{Acknowledgements}

This study was partly initiated by the European Union in a project entitled: "Surveillance network of Reoviruses, Bluetongue and African Horse Sickness, in the Mediterranean basin and Europe" (MedReoNet) (Contract N 044285). We thank Concepción Gómez Tejedor and Montserrat Agüero (Laboratorio Central de Veterinaria Algete) for making the Spanish isolates available. We are thankful to Ina Hermanides, Isabel Wright, Daphney Majatladi and Solomon Boikanyo for technical assistance. We thank Eva Veronesi (IAH Pirbright) and Truuske Gerdes for constructive comments on earlier drafts of this manuscript. We also would like to thank to the "Conselleria d'Innovació, Interior i Justicia" and to the national project called "Estudio de la competencia vectorial de las especies de Culicoides (Diptera: Ceratopogonidae) vectores de la Lengua Azul en España y evaluación de la hibernación del virus en los vectores" for their economical support.

\section{References}

Acevedo, P., Ruiz-Fons, F., Estrada, R., Luz Marquez, A., Angel Miranda, M., Gortazar, C. Lucientes, J. (2010) A Broad Assessment of Factors Determining Culicoides imicola Abundance: Modeling the Present and Forecasting Its Future in Climate Change Scenarios. Plos One, 5(11), pp. e14236.

Allepuz, A., García-Bocanegra, I., Napp, S., Casal, J., Arenas, A., Saez, M. \& González, M.A. (2010) Monitoring bluetongue disease (BTV-1) epidemic in southern Spain during 2007. Preventive Veterinary Medicine, 96, 263-271.

Bonneau, K.R., DeMaula, C.D., Mullens, B.A. \& MacLachlan, N.J. (2002) Duration of viraemia infectious to Culicoides sonorensis in bluetongue virus-infected cattle and sheep.

Veterinary Microbiology, 88, 115-125. 
Boorman, J. (1986) Presence of bluetongue virus vectors on Rhodes. The Veterinary Record, 118, 21-21.

Borden, E.C., Shope, R.E. \& Murphy, F.A. (1971) Physiochemical and morphological relationships of some arthropod-borne viruses to bluetongue virus - a new taxonomic group. Physiochemical and serological studies. Journal of General Virology, 13, 261-271.

Calvete, C., Miranda, M.A., Estrada, R., Borras, D., Sarto i Monteys, V. \& Collantes, F. (2006) Spatial distribution of Culicoides imicola, the main vector of bluetongue virus. The Veterinary Record, 158, 130-131.

Campano-López, A. \& Sanchez-Botija, C. (1958) L'epizootie de fievre catarrhale ovine en Espagne (Blue Tongue). Bulletin - Office international des épizooties . 50, 65-83.

Carpenter, S., Lunt, H.L., Arav, D., Venter, G.J. \& Mellor, P.S. (2006) Oral susceptibility to bluetongue virus of Culicoides (Diptera: Ceratopogonidae) from the United Kingdom. Journal of Medical Entomology, 43, 73-78.

Carpenter, S., Wilson, A. \& Mellor, P.S. (2009) Culicoides and the emergence of bluetongue virus in northern Europe. Trends in Microbiology, 17, 172-178.

Chiang, C. L. \& Reeves, W. C. (1962) Statistical estimation of virus infection rates in mosquito vector populations. American Journal of Hygiene, 75, 377-391.

Erasmus, B.J. \& Potgieter, C. (2009) The history of bluetongue. Bluetongue (ed. by P. Mellor, M. Baylis and P. Mertens) pp. 7-21. Elsevier, London.

Ferrari, C., De Liberato, C., Scavia, G., Lorenzetti, R., Zini, M., Farina, F., Magliano, A., Cardeti, G., Scholl, F., Guidoni, M., Scicluna, M.T., Amaddeo, D., Scaramozzino, P., Autorino, G.L. (2005) Active circulation of bluetongue vaccine virus serotype-2 among unvaccinated cattle in central Italy. Preventive Veterinary Medicine, 68, 103-113. 
Fu, H., Leake, C.J., Mertens, P.P.C. \& Mellor, P.S. (1999) The barriers to bluetongue virus infection, dissemination and transmission in the vector, Culicoides variipennis (Diptera: Ceratopogonidae). Archives of Virology, 144, 747-761.

Gerry, A. C., Mullens, B.A., MacLachlan, N.J. \& Mecham, J.O. (2001) Seasonal transmission of bluetongue virus by Culicoides sonorensis (Diptera: Ceratopogonidae) at a southern California dairy and evaluation of vectorial capacity as a predictor of bluetongue virus transmission. Journal of Medical Entomology, 38, 197-209.

Giovannini, A., Calistri, P., Conte, A., Savini, L., Nannini, D., Patta, C., Santucci, U. \& Caporale, V. (2004) Bluetongue virus surveillance in a newly infected area. Veterinaria Italiana, 40, 188-197.

Goffredo, M., Satta, G., Torina, A., Federico, G., Scaramozzino, P., Cafiero, M.A., Lelli, R. \& Meiswinkel, R. (2001) The 2000 bluetongue virus (BTV) outbreak in Italy: distribution and abundance of the principal vector Culicoides imicola Kieffer, Proceedings of the 10th International Symposium of the American Association of Veterinary Laboratory Diagnosticians (AAVLD) and OIE Seminar on biotechnology, Salsomaggiore, Parma, 2001, pp. 4-7.

Gómez-Tejedor, C. (2004) Brief overview of the bluetongue situation in Mediterranean Europe, 1998-2004. Veterinaria Italiana, 40, pp. 57-60.

Hoffmann, B.; Sasserath,M.; Thalheim,S.; Bunzenthal,C.; Strebelow,G.; Beer,M. (2008) Bluetongue Virus Serotype 8 Reemergence in Germany, 2007 and 2008. Emerging Infectious Diseases, 14 (9), pp. 1421-1423

House, C., Mikiciuk, P.E. \& Berninger, M.L. (1990) Laboratory diagnosis of African horse sickness: comparison of serological techniques and evaluation of storage methods of samples for virus isolation. Journal of Veterinary Diagnostic Investigations, 2, 44-50. Jennings, D.M. \& Mellor, P.S. (1987) Variation in the responses of Culicoides variipennis (Diptera, Ceratopogonidae) to oral infection with bluetongue virus. Archives of Virology, 95, 177-182. 
Jones, R.H. \& Foster, N.M. (1978) Heterogeneity of Culicoides variipennis field populations to oral infection with bluetongue virus. The American Journal of Tropical Medicine and Hygiene, 27, 178-183.

Kärber, G. (1931) Beitrag zur kollectiven Behandlund pharmkologischer Reihenversuche. Archiv fur Experimentelle Patologie Pharmakologie, 162, 480-483.

Lorca, C., Pujols, J., Arenas, A., Gómez-Guillamón, F., Zorrilla, I., Domingo, M., ArenasMontés, A., Ruano, M.J. \& García-Bocanegra, I. (2011) Epidemiological surveillance of bluetongue virus serotypes 1; 4 and 8 in Spanish ibex (Capra pyrenaica hispanica) in southern Spain. Veterinary Microbiology, 149, 230-235.

Maan, S.; Maan, N.S.; Nomikou, K.; Batten, C.; Antony, F.; Belaganahalli, M.N.; Samy, A.M.; Reda, A.A.; Al-Rashid, S.A.; El Batel, M. (2011) Novel Bluetongue Virus Serotype from Kuwait. Emerging infectious diseases. 17 (5), 885-889

Manso-Ribeiro, J. \& Norenha, F.M.O. (1958) Fievre catarrhale du mouton au Portugal (Blue Tongue). Bulletin - Office international des épizooties, 50, 46-64.

Meiswinkel, R., Venter, G.J. \& Nevill, E.M. (2004) Vectors: Culicoides spp. Infectious Diseases of Livestock (ed. by J.A.W. Coetzer \& R.C. Tustin), pp. 93-136. Oxford University Press, Cape Town.

Mellor, P.S. (1992) Culicoides as potential orbivirus vectors in Europe. Bluetongue, African horse sickness, and Related Orbiviruses. (ed. by E. Walton and B.I. Osburn) pp. 278-283. CRC Press, Inc. Boca Raton, Florida.

Mellor, P.S. (2004) Infection of the vectors and bluetongue epidemiology in Europe.

Veterinaria Italiana, 40, 167-174.

Mellor, P.S., Boorman, J. \& Baylis, M. (2000) Culicoides biting midges: their role as arbovirus vectors. Annual Review of Entomology, 45, 307-340.

Mellor, P.S., Carpenter, S., Harrup, L., Baylis, M. \& Mertens, P.P. (2008) Bluetongue in Europe and the Mediterranean Basin: History of occurrence prior to 2006. Preventive Veterinary Medicine, 87, 4-20. 
Mellor, P.S., Carpenter, S. \& White, D.V. (2009) Bluetongue virus in the insect host.

Bluetongue (ed. by P. Mellor, M. Baylis and P. Mertens) pp. 295-320. Elsevier, London. Mellor, P.S., Jennings, D.M., Wilkinson, P.J. \& Boorman, J.P.T. (1985) Culicoides imicola: a bluetongue virus vector in Spain and Portugal. The Veterinary Record, 116, 589-590.

Mellor, P.S. \& Pitzolis, G. (1979) Observations on breeding sites and light trap collections of Culicoides during an outbreak of bluetongue in Cyprus. Bulletin of Entomological Research, 69, 229-234.

Mellor, P.S. \& Wittmann E.J. (2002) Bluetongue virus in the Mediterranean basin, 1998-2001. The Veterinary Journal, 164, 20-37.

Miranda, M.A., Borr, S,D., Rinc $\notin n$, C. \& Alemany, A. (2003) Presence in the Balearic Islands (Spain) of the midges Culicoides imicola and Culicoides obsoletus group. Medical and Veterinary Entomology, 17, 54-54.

Mullens, B.A., Gerry, A.C., Lysyk, T.J. \& Schmidtmann, E.T. (2004) Environmental effects on vector competence and virogenesis of bluetongue virus in Culicoides: interpretating laboratory data in a field context. Veterinaria Italiana, 40, 160-166.

Muller, M.J., Standfast, H.A., St George, T.D. \& Cybinski, D.H. (1982) Culicoides brevitarsis (Diptera: Ceratopogonidae) as a vector of arboviruses in Australia. Proceedings of the Third Symposium of Arbovirus Research in Australia (ed. by T.D. St George \& B.H. Kay), pp. 43-49. Queensland Institute of Medical Research, Brisbane.

Nevill, E.M., Erasmus, B.J. \& Venter, G.J. (1992a) A six-year survey of viruses associated with Culicoides biting midges throughout South Africa (Diptera: Ceratopogonidae).

Bluetongue, African Horse Sickness and, Related Orbiviruses. (ed. by T.E. Walton \& B.I. Osburn), pp. 314-319. CRC Press, Boca Raton, Florida.

Nevill, E.M., Venter, G.J. \& Edwardes, M. (1992b) Potential Culicoides vectors of livestock orbiviruses in South Africa. Bluetongue, African Horse Sickness and Related Orbiviruses (ed. by T.E. Walton \& B.I. Osburn), pp. 306-314. CRC Press Inc., Boca Raton, Florida. OIE (2006) Bluetongue detected for the first time in Northern Europe. Press release. 2006 Aug 23 [cited 2006 Dec 29]. Available from http://www.oie.int/eng/press/en_060823.htm 
OIE (2009) (http://www.oie.int/fileadmin/Home/eng/Animal Health in the

World/docs/pdf/BLUETONGUE FINAL.pdf.

Paweska, J.T., Venter, G.J. \& Mellor, P.S. (2002) Vector competence of South African

Culicoides species for bluetongue virus serotype 1 (BTV-1) with special reference to the effect of temperature on the rate of virus replication in C. imicola and C. bolitinos. Medical and Veterinary Entomology, 16, 10-21.

Purse, B.V., Mellor, P.S., Rogers, D.J., Samuel, A.R., Mertens, P.P.C. \& Baylis, M. (2005) Climate change and the recent emergence of bluetongue in Europe. Nature Reviews Microbiology, 3, 171- 181.

Riegler, L. (2002) Variation in African horse sickness virus and its effect on the vector competence of Culicoides biting midges. PhD Thesis. University of Surrey, Guildford, UK.

Sabirovic, M., Roberts, H., Papadopoulou, C., Lopez, M., Hancock, R. \& Calistri, P. (2009) International disease monitoring, July to September 2009. The Veterinary Record, 165, $552-555$

Sarto i Monteys, V., Ventura, D., Pages, N., Aranda, C. \& Escosa, R. (2005) Expansion of Culicoides imicola, the main bluetongue virus vector in Europe, into Catalonia, Spain. The Veterinary Record, 156, 415-415.

Savini, G., Goffredo, M., Monaco, F., Di Gennaro, A., Cafiero, M.A., Baldi, L., de Santis, P., Meiswinkel, R. \& Caporale, V. (2005) Bluetongue virus isolations from midges belonging to the Obsoletus complex (Culicoides, Diptera: Ceratopogonidae) in Italy. The Veterinary Record, 157, 133-139.

Sellers, R.F., Pedgley, D.E. \& Tucker, M.R. (1978) Possible windborne spread of bluetongue to Portugal, June-July 1956. The Journal of Hygiene, 81, 189-196.

Venter, G.J., Koekemoer, J.J.O. \& Paweska, J.T. (2006) Investigations on outbreaks of African horse sickness in the surveillance zone of South Africa. Revue scientifique et technique, Office International des Epizooties, 25, 1097-1019. 
Venter, G.J. \& Paweska, J.T. (2007) Virus recovery rates for wild-type and live-attenuated vaccine strains of African horse sickness virus serotype 7 in orally infected South African Culicoides species. Medical and Veterinary Entomology, 21, 377-383.

Venter, G.J., Paweska, J.T., Lunt, H., Mellor, P.S. \& Carpenter, S. (2005) An alternative method of blood-feeding Culicoides imicola and other haematophagus Culicoides species for vector competence studies. Veterinary Parasitology, 131, 331-335.

Venter, G.J., Paweska, J.T., Van Dijk, A.A., Mellor, P.S. \& Tabachnick, W.J. (1998) Vector competence of Culicoides bolitinos and C. imicola (Diptera: Ceratopogonidae) for South African bluetongue virus serotypes 1,3 and 4. Medical and Veterinary Entomology, 12, $378-385$.

Venter, G.J., Wright, I.M., Del Rio, R., Lucientes, J. \& Miranda, M.A (2010) The susceptibility of Culicoides imicola and other South African livestock-associated Culicoides species to infection with bluetongue virus serotype 8. Medical and Veterinary Entomology, doi: 10.1111/j.1365-2915.2010.00931.x

Walter, S. D., Hildreth, S. W. \& Beaty, B. J. (1980) Estimation of infection rates in populations of organisms using pools of variable size. American Journal of Epidemiology, 112, 124128.

Walton, T.E. (2004) The history of bluetongue and a current global overview. Veterinaria Italiana, 40, 31-38.

Ward, M.P. (1994) The epidemiology of bluetongue virus in Australia - a review. Australian Veterinary Journal, 71, 3-7. 
Table 1. Virus serotypes, year of isolation and passage history of the Spanish BTV isolates used for the oral infection of field collected Culicoides midges

\begin{tabular}{lccc}
\hline Virus Serotype & Strain identification & Year of isolation & Passage history* \\
\hline BTV-1 & SPA/07 & 2007 & 1P Vero \\
BTV-2 & $\mathbf{R 2 3 / 0 0}$ & 2000 & 2P BHK-21 \\
BTV-4 & SPA/04 & 2004 & 3P BHK-21 \\
BTV-8 & Segovia & & 2P BHK-21 \\
\hline
\end{tabular}

* number of passages in baby hamster kidney cells (BHK-21) or Vero cells

Table 2. Virus recovery rates and titres in field collected Culicoides imicola, C. bolitinos, $C$. enderleini and C. nevilli maintained for 10 days at $23.5^{\circ} \mathrm{C}$ after feeding on blood containing different serotypes of BTV

\begin{tabular}{lcccc}
\hline \multicolumn{1}{c}{ BTV serotype } & BTV-1 & BTV-2 & BTV-4 & BTV-8 \\
\hline Virus titre of blood meal & 6.4 & 5.1 & 5.8 & 6.1 \\
$\log _{10} \mathrm{TCID}_{50} / \mathrm{ml}$ & & & & \\
C. imicola $(\%)$ & $1 / 490^{1}(0.2 \%)$ & $4 / 889(0.5 \%)$ & $1 / 404(0.2 \%)$ & $0 / 492(0.0 \%)$ \\
Avg Virus titre/midge & 3.9 & 2.5 & 2.4 & - \\
Range in virus titre & & $1.4-3.2$ & & $0 / 5$ \\
C. bolitinos & $0 / 2$ & $0 / 2$ & $0 / 11$ & $0 / 8$ \\
C. enderleini & $0 / 1$ & & $0 / 1$ & $0 / 2$ \\
C. nevilli & & & & \\
\hline
\end{tabular}

${ }^{1}$ No positive/No tested, ${ }^{2} \log _{10}$ TCID $_{50} /$ midge 